\title{
Mutation analysis of Leber's hereditary optic neuropathy using a multi-gene panel
}

\author{
YU DAI $^{1 *}$, CHENGHUI WANG $^{2,3^{*}}$, ZHIPENG NIE ${ }^{2,3}$, JIAMIN HAN $^{3}$, TING CHEN $^{2}$, XIAOXU ZHAO $^{2,3}$, \\ $\mathrm{CHENG} \mathrm{AI}^{3}$, YANCHUN JI ${ }^{2}$, TAO GAO ${ }^{1}$ and PINGPING JIANG ${ }^{2,3}$ \\ ${ }^{1}$ The Second Affiliated Hospital, Zhejiang University School of Medicine, Hangzhou, Zhejiang 310009; \\ ${ }^{2}$ Division of Medical Genetics and Genomics, The Children's Hospital, Zhejiang University School of Medicine; \\ ${ }^{3}$ Institute of Genetics, Zhejiang University, and Department of Genetics, Zhejiang University \\ School of Medicine, Hangzhou, Zhejiang 310058, P.R. China
}

Received August 10, 2017; Accepted October 2, 2017

DOI: $10.3892 /$ br.2017.1014

\begin{abstract}
The present study investigates the spectrum and incidence of mitochondrial DNA (mtDNA) mutations associated with Leber's hereditary optic neuropathy (LHON) in a Han population using a multi-gene panel with 46 LHON-associated mutations among 13 mitochondrial genes. A total of 23 mutations were observed in a cohort of 275 patients and 281 control subjects using multi-gene panel analysis. The causative mutations associated with LHON were identified to be m.11778G $>\mathrm{A}, \mathrm{m} .14484 \mathrm{~T}>\mathrm{C}, \mathrm{m} .3460 \mathrm{G}>\mathrm{A}$, m.3635G $>$ A, m.3866T $>C$ and $m .3733 \mathrm{G}>\mathrm{A}$, responsible for $70.55 \%$ cases in the patient cohort. The secondary mutations in the Chinese LHON population were m.12811T $>$ C, m.11696 $\mathrm{G}>\mathrm{A}, \mathrm{m} .3316 \mathrm{G}>\mathrm{A}, \mathrm{m} .3394 \mathrm{~T}>\mathrm{C}, \mathrm{m} .14502 \mathrm{~T}>\mathrm{C}, \mathrm{m} .3497 \mathrm{C}>\mathrm{T}$, $\mathrm{m} .3571 \mathrm{C}>\mathrm{T}, \mathrm{m} .12338 \mathrm{~T}>\mathrm{C}, \mathrm{m} .14693 \mathrm{~A}>\mathrm{G}, \mathrm{m} .4216 \mathrm{~T}>\mathrm{C}$ and m.15951A $>\mathrm{G}$, with incidences of 5.09, 4.36, 4.00, 4.00, 4.00, $2.55,1.82,1.82,1.45,1.09$ and $1.09 \%$, respectively. Besides three hotspot genes, $M T-N D 1, M T-N D 4$ and $M T-N D 6$, $M T-N D 5$ also had a high incidence of secondary mutations. Those mutations reported as rare causative mutations in a European LHON population, m.3376G $>$ A, m.3700G $>$ A and m.4171C $>$ A, m.10663T $>$ C $, \mathrm{m} .13051 \mathrm{G}>\mathrm{A}, \mathrm{m} .14482 \mathrm{C}>\mathrm{G} / \mathrm{A}$, $\mathrm{m} .14495 \mathrm{~A}>\mathrm{G}$ and $\mathrm{m} .14568 \mathrm{C}>\mathrm{T}$ were undetected in the present study. The primary and secondary mutations associated
\end{abstract}

Correspondence to: Dr Pingping Jiang, Institute of Genetics, Zhejiang University, and Department of Genetics, Zhejiang University School of Medicine, 866 Yuhangtang Road, Hangzhou, Zhejiang 310058, P.R. China

E-mail: ppjiang@zju.edu.cn

*Contributed equally

Abbreviations: LHON, Leber's hereditary optic neuropathy; mtDNA, mitochondrial DNA

Key words: Leber's hereditary optic neuropathy, mitochondrial DNA, causative mutation, multi-gene panel, gene-target sequencing with LHON in the present multi-gene panel will advance the current understanding of the clinical phenotype of LHON, and provide useful information for early diagnosis.

\section{Introduction}

Leber's hereditary optic neuropathy (LHON; OMIM 535000) is a classic mitochondrial disease, associated with a rapid, painless, acute or sub-acute bilateral visual loss in young adults, predominantly caused by the primary and secondary mutations in mitochondrial DNA (mtDNA). It has been reported that 1:8,500 individuals harbor a primary LHON-causing mutation and 1:31,000 experience visual loss as a result of LHON in the North East of England (1). Few significant improvements in visual acuity are reported following atrophy of the optic discs. LHON typically affects males more frequently than females, with the incomplete and variable penetrance estimated at $50 \%$ in males and $10 \%$ in females (2-4). Additionally, certain LHON cases have additional clinical symptoms, such as movement disorders, dystonia, and multiple-sclerosis-like illness, which complicate the diagnosis in the clinical setting (5-7). Although the majority ofcases of LHON transmitted by maternal inheritance have a history of visual loss in families, up to $40 \%$ of cases are sporadic (5).

The genetic cause of LHON is mutations in the mitochondrial genome, which is a double-stranded 16,569-nucleotide pair, circular molecule, consisting of one D-Loop region and 37 genes. The three most causative mutations, m.11778G $>\mathrm{A}$ $(M T-N D 4), \mathrm{m} .14484 \mathrm{~T}>\mathrm{C}(M T-N D 6)$ and $\mathrm{m} .3460 \mathrm{G}>\mathrm{A}$ (MT-ND1), have been reported to account for $90 \%$ of LHON patients in a Caucasian population, but for only 38.3 and $46.5 \%$ of cases in two large cohorts of Chinese Han subjects with LHON (7-10). Our previous studies have shown the spectrum of genes, MT-ND1,MT-ND4 and MT-ND6, and the frequency of the three primary mutations in a Chinese LHON population (8-10) using Sanger sequencing. In addition, secondary mutations that contributed to the high penetrance, including m.3394T>C $(M T-N D 1), \mathrm{m} .11696 \mathrm{G}>\mathrm{A}(M T-N D 4), \mathrm{m} .12338 \mathrm{~T}>\mathrm{C}$ (MT-ND5) and m.15951A $>\mathrm{G}(M T-T T)$ areusually synergized with $\mathrm{m} .11778 \mathrm{G}>\mathrm{A}$ or $\mathrm{m} .14484 \mathrm{~T}>\mathrm{C}$ or $\mathrm{m} .3460 \mathrm{G}>\mathrm{A}$ (11). According to Mitomap (http://www.mitomap.org/), >40 point 
mutations in mtDNA are associated with LHON, of which the incidence varies between different ethnic backgrounds.

To further understand the spectrum of mutations associated with LHON in a Chinese population, 46 LHON-associated mutations distributed among 13 mitochondrial genes were selected from Mitomap, and multi-gene target sequencing was performed in 275 cases of LHON as well as in 281 Chinese control subjects to distinguish the most frequent mtDNA mutations associated with LHON in the Han population.

\section{Materials and methods}

DNA samples, extraction, quantification and quality control. A total of 275 unrelated LHON samples and 281 Chinese control samples were enrolled from the ophthalmology clinics at Zhejiang University School of Medicine (Hangzhou, China) and Wenzhou Medical College (Wenzhou, China) between 2004 and 2015, as described previously $(8-10,12)$, under protocols approved by Zhejiang University and Wenzhou Medical University Ethics Committees. DNA was extracted from $1 \mathrm{ml}$ peripheral blood using a QIAamp DNA Blood Minikit (51106; Qiagen China Co., Ltd., Shanghai, China). The quality and quantity of DNA were assessed using Qubit 3.0 fluorometers (Thermo Fisher Scientific, Inc., Waltham, MA, USA). DNA samples with concentration $>1.0 \mathrm{ng} / \mu 1$ were employed in the sequencing experiments.

Multi-genepanel design. Multi-gene target sequencing was performed using the VariantPro ${ }^{\mathrm{TM}}$ Capture Technology by LC Sciences (Hangzhou, China) as described previously (13). The 46 LHON-associated mutations were selected from Mitomap and previous studies (8-10). As presented in Table I, they were distributed in the following 13 genes: $M T-N D 1, M T-N D 2$, MT-ATP6,MT-CO3,MT-ND3,MT-ND4L,MT-ND4,MT-ND5, $M T-N D 6, M T-C Y B, M T-T M, M T-T T$ and $M T-T E$. Twenty-seven amplicons that covered all 46 mutations were designed by LC Sciences, as described previously (13). All amplicons were pooled into two polymerase chain reaction (PCR) tubes (tube 1 and tube 2) as VariantPro ${ }^{\mathrm{TM}}$ PCR mastermix with an average length of $184 \mathrm{nt}$ (range, 167-203 nt).

Library preparation and sequencing. Library generation was performed according to the manufacturer's protocol (LC Sciences). Briefly, 5 ng DNA per pool was amplified in 25 cycles of PCR using probe sequences of 27 library amplicons (Table II) and a VariantPro ${ }^{\mathrm{TM}}$ PCR mastermix as described previously (13). PCR runs of 18, 20, 24 and 26 cycles were performed to evaluate the influence of the PCR cycles on the experiment. The correlation coefficient, $\mathrm{R}^{2}$, ranged from 0.90-1.00 (average, 0.95), implicating that cycles between 18 and 26 had no influence on the experiment outcome. The amplified products were purified using Agencourt AMPure XP beads [Beckman Coulter (UK) Ltd., High Wycombe, UK]. Each library was diluted to $20 \mathrm{pM}$ and sequenced on an Illumina Miseq with a minimum of $2 \mathrm{X}$ 150 -bp paired-end reads.

Data analysis. Low quality reads (reads containing sequencing adaptors or nucleotides with quality scores $<20$ ) were removed before alignment. Cleaned, paired-end sequence reads in paired FASTQ files were aligned using Burrows-Wheeler Alignment version 0.1.19 (14). Variant calling was generated using the Genome Analysis Toolkit version 3.3.0 and its Unified Genotyper module (https://www.broadinstitute. org/gatk/guide/tagged?tag=unifiedgenotyper). A Gaussian mixture model was used to evaluate the confidence score for each putative mutation call and novel potential variants. Sequence reads were aligned to the human mtDNA sequence data relative to the revised Cambridge Reference Sequence (GenBank accession no. NC_012920) (15).

Sanger validation. Thirteen $\mathrm{LHON}$ cases associated with m.11778G $>$ A (11) or m.14484T $>$ C (2) mutations and four healthy control samples (available upon request) were selected as the positive and negative controls, respectively, for runs of the panel following validation by Sanger sequencing. Furthermore, $100 \%$ correlation was derived from the panel assay and the Sanger sequencing for the positive and negative controls.

\section{Results}

Summary of sequencing data. A total of 118 milion reads were obtained, on average $89 \%$ of which were mapped to the amplicon targets and resultedin a mean of 7,001 reads to each sample per amplicon (Table III). The mean reads over the 27 amplicons were distrubed with an average uniformity of coverage of $98.0 \%$ (amplicon mean coverage, 20\%) and an average read-depth of $1,000 \mathrm{X}$ (Fig. 1). A total of 363 variants were distributed in $46 \mathrm{LHON}$-associated mutations of all samples.

Mutations analysis. A total of 363 variants were identified in the cohort of all 556 samples; 285 variants were detected in LHON cases as an average incidence of $104 \%$, whereas only 78 variants were identified in 281 controls with a mean incidence of $28 \%$ (Table IV).

As 46 mutations of 13 mitochondrial genes were selected from all populations of the world, variants from LHON cases in the current study were deposited in 8 mitochondrial genes, MT-ND1, MT-CO3, MT-ND4, MT-ND5, MT-ND6, MT-CYB, MT-TT and MT-TE, with frequencies of 16.14, 0.35, 61.40, $6.67,12.63,0.35,1.05$ and $1.40 \%$, respectively. Consistent with our previous reports (8-10), MT-ND1, MT-ND4 and MT-ND6 were the hotspots associated with LHON, and almost cover $90 \%$ of variants in the present study.

Twenty-three out of the 46 LHON-associated mutations were detected in all subjects. These were as follows: $3316 \mathrm{G}>\mathrm{A}$, $3394 \mathrm{~T}>\mathrm{C}, 3460 \mathrm{G}>\mathrm{A}, 3497 \mathrm{C}>\mathrm{T}, 3571 \mathrm{C}>\mathrm{T}, 3635 \mathrm{G}>\mathrm{A}$, $3733 \mathrm{G}>\mathrm{A}, 3866 \mathrm{~T}>\mathrm{C}, 4025 \mathrm{C}>\mathrm{T}$ and $4216 \mathrm{~T}>\mathrm{C}$ mutations in $M T-N D 1,9804 \mathrm{G}>\mathrm{A}$ in $M T-C O 3,11253 \mathrm{~T}>\mathrm{C}, 11696 \mathrm{G}>\mathrm{A}$ and $11778 \mathrm{G}>\mathrm{A}$ in $M T-N D 4, \mathrm{~m} .12338 \mathrm{~T}>\mathrm{C}$ and $12811 \mathrm{~T}>\mathrm{C}$ in $M T-N D 5,14325 \mathrm{~T}>\mathrm{C}, 14484 \mathrm{~T}>\mathrm{C}$ and $14502 \mathrm{~T}>\mathrm{C}$ in $M T-N D 6$, $14831 \mathrm{G}>\mathrm{A}$ and $15812 \mathrm{G}>\mathrm{A}$ in $M T-C Y B, 15951 \mathrm{~A}>\mathrm{G}$ in $M T-T T$ and $14693 \mathrm{~A}>\mathrm{G}$ in $M T-T E$. The incidence of these three common mutations m.11778G $>$ A, m.14484T $>$ C and $\mathrm{m} .3460 \mathrm{G}>\mathrm{A}$ in this Chinese cohort were $58.90,9.10$ and $0.73 \%$, respectively. In addition, two causative mutations were detected; $\mathrm{m} .3635 \mathrm{G}>\mathrm{A}$ in 1 patient and $\mathrm{m} .3866 \mathrm{~T}>\mathrm{C}$ in 4 patients (one case carrying both $\mathrm{m} .11778 \mathrm{G}>\mathrm{A}$ and $\mathrm{m} .3866 \mathrm{~T}>\mathrm{C}$ mutations), as reported 
Table I. Mutations in the multi-gene panel $(n=46)$.

\begin{tabular}{|c|c|c|c|c|c|c|}
\hline Index & Gene name & Var start & Var end & Ref allele & Var allele & Amino acid change \\
\hline 1 & $M T-N D 1$ & 3316 & 3316 & G & A & A-T \\
\hline 2 & $M T-N D 1$ & 3376 & 3376 & $\mathrm{G}$ & $\mathrm{A}$ & E-K \\
\hline 3 & $M T-N D 1$ & 3394 & 3394 & $\mathrm{~T}$ & $\mathrm{C}$ & Y-H \\
\hline 4 & $M T-N D 1$ & 3460 & 3460 & G & A & $\mathrm{A}-\mathrm{T}$ \\
\hline 5 & $M T-N D 1$ & 3497 & 3497 & $\mathrm{C}$ & $\mathrm{T}$ & $A-V$ \\
\hline 6 & $M T-N D 1$ & 3571 & 3571 & $\mathrm{C}$ & $\mathrm{T}$ & L-F \\
\hline 7 & $M T-N D 1$ & 3635 & 3635 & G & $\mathrm{A}$ & $\mathrm{S}-\mathrm{N}$ \\
\hline 8 & $M T-N D 1$ & 3700 & 3700 & G & A & A-T \\
\hline 9 & $M T-N D 1$ & 3733 & 3733 & $\mathrm{G}$ & A & E-K \\
\hline 10 & $M T-N D 1$ & 3866 & 3866 & $\mathrm{~T}$ & $\mathrm{C}$ & $\mathrm{I}-\mathrm{T}$ \\
\hline 11 & $M T-N D 1$ & 4025 & 4025 & $\mathrm{C}$ & $\mathrm{T}$ & $\mathrm{T}-\mathrm{M}$ \\
\hline 12 & $M T-N D 1$ & 4171 & 4171 & $\mathrm{C}$ & $\mathrm{A}$ & L-M \\
\hline 13 & $M T-N D 1$ & 4216 & 4216 & $\mathrm{~T}$ & $\mathrm{C}$ & Y-H \\
\hline 14 & $M T-N D 2$ & 4640 & 4640 & $\mathrm{C}$ & A & $\mathrm{I}-\mathrm{M}$ \\
\hline 15 & $M T-N D 2$ & 5244 & 5244 & $\mathrm{G}$ & A & G-S \\
\hline 16 & MT-ATP6 & 9101 & 9101 & $\mathrm{~T}$ & $\mathrm{C}$ & $\mathrm{I}-\mathrm{T}$ \\
\hline 17 & MT-CO3 & 9804 & 9804 & G & A & A-T \\
\hline 18 & $M T-N D 3$ & 10237 & 10237 & $\mathrm{~T}$ & $\mathrm{C}$ & $\mathrm{I}-\mathrm{T}$ \\
\hline 19 & $M T-N D 4 L$ & 10663 & 10663 & $\mathrm{~T}$ & $\mathrm{C}$ & $\mathrm{V}-\mathrm{A}$ \\
\hline 20 & $M T-N D 4 L$ & 10680 & 10680 & G & A & A-T \\
\hline 21 & $M T-N D 4$ & 11253 & 11253 & $\mathrm{~T}$ & $\mathrm{C}$ & $\mathrm{I}-\mathrm{T}$ \\
\hline 22 & $M T-N D 4$ & 11696 & 11696 & G & A & V-I \\
\hline 23 & $M T-N D 4$ & 11778 & 11778 & $\mathrm{G}$ & A & $\mathrm{R}-\mathrm{H}$ \\
\hline 24 & $M T-N D 5$ & 12338 & 12338 & $\mathrm{~T}$ & $\mathrm{C}$ & $\mathrm{M}-\mathrm{T}$ \\
\hline 25 & $M T-N D 5$ & 12811 & 12811 & $\mathrm{~T}$ & $\mathrm{C}$ & $\mathrm{Y}-\mathrm{H}$ \\
\hline 26 & $M T-N D 5$ & 12848 & 12848 & $\mathrm{C}$ & $\mathrm{T}$ & $A-V$ \\
\hline 27 & $M T-N D 5$ & 13051 & 13051 & $\mathrm{G}$ & A & G-S \\
\hline 28 & $M T-N D 5$ & 13528 & 13528 & A & G & $\mathrm{T}-\mathrm{A}$ \\
\hline 29 & $M T-N D 5$ & 13637 & 13637 & A & G & Q-R \\
\hline 30 & $M T-N D 5$ & 13730 & 13730 & G & A & G-E \\
\hline 31 & $M T-N D 6$ & 14279 & 14279 & $\mathrm{G}$ & A & S-L \\
\hline 32 & $M T-N D 6$ & 14325 & 14325 & $\mathrm{~T}$ & $\mathrm{C}$ & N-D \\
\hline 33 & $M T-N D 6$ & 14482 & 14482 & $\mathrm{C}$ & A & M-I \\
\hline 34 & $M T-N D 6$ & 14482 & 14482 & $\mathrm{C}$ & G & M-I \\
\hline 35 & $M T-N D 6$ & 14484 & 14484 & $\mathrm{~T}$ & $\mathrm{C}$ & $\mathrm{M}-\mathrm{V}$ \\
\hline 36 & $M T-N D 6$ & 14495 & 14495 & A & G & L-S \\
\hline 37 & $M T-N D 6$ & 14498 & 14498 & $\mathrm{~T}$ & $\mathrm{C}$ & Y-C \\
\hline 38 & $M T-N D 6$ & 14502 & 14502 & $\mathrm{~T}$ & $\mathrm{C}$ & $\mathrm{I}-\mathrm{V}$ \\
\hline 39 & $M T-N D 6$ & 14568 & 14568 & $\mathrm{C}$ & $\mathrm{T}$ & G-S \\
\hline 40 & $M T-N D 6$ & 14596 & 14596 & A & $\mathrm{T}$ & I-M \\
\hline 41 & $M T-C Y B$ & 14831 & 14831 & G & A & A-T \\
\hline 42 & $M T-C Y B$ & 15812 & 15812 & G & A & V-M \\
\hline 43 & $M T-T M$ & 4435 & 4435 & A & G & tRNAMet \\
\hline 44 & $M T-T T$ & 15951 & 15951 & A & G & tRNAThr \\
\hline 45 & $M T-T E$ & 14693 & 14693 & A & $\mathrm{G}$ & tRNAGlu \\
\hline 46 & $M T-T E$ & 14727 & 14727 & $\mathrm{~T}$ & C & tRNAGlu \\
\hline
\end{tabular}

Var start, start site of variant; var end, end site of variant; ref allele, referenced allele; Var allele, variant allele. 
Table II. PCR amplicons.

\begin{tabular}{|c|c|c|c|c|c|c|c|c|c|c|}
\hline Index & Gene name & Tgt start & Tgt end & Prb strand & Prb start & Prb end & Var start & Var end & $\begin{array}{l}\text { Prb length } \\
\text { (bp) }\end{array}$ & $\begin{array}{c}\text { Amp length } \\
\text { (bp) }\end{array}$ \\
\hline 1 & $M T-N D 1$ & 3,316 & 3,866 & - & 3,269 & 3,439 & 3,288 & 3,425 & 171 & 303 \\
\hline 2 & $M T-N D 1$ & 3,316 & 3,866 & + & 3,402 & 3,585 & 3,415 & 3,571 & 184 & 316 \\
\hline 3 & $M T-N D 1$ & 3,316 & 3,866 & - & 3,526 & 3,699 & 3,543 & 3,684 & 174 & 306 \\
\hline 4 & $M T-N D 1$ & 3,316 & 3,866 & + & 3,643 & 3,812 & 3,661 & 3,794 & 170 & 302 \\
\hline 5 & $M T-N D 1$ & 3,316 & 3,866 & - & 3,745 & 3,936 & 3,767 & 3,918 & 192 & 324 \\
\hline 6 & $M T-N D 1$ & 4,025 & 4,025 & - & 3,952 & 4,140 & 3,962 & 4,126 & 189 & 321 \\
\hline 7 & $M T-N D 1$ & 4,171 & 4,216 & + & 4,132 & 4,334 & 4,145 & 4,315 & 203 & 335 \\
\hline 8 & $M T-T M$ & 4,435 & 4,435 & - & 4,363 & 4,529 & 4,380 & 4,514 & 167 & 299 \\
\hline 9 & $M T-N D 2$ & 4,640 & 4,640 & - & 4,482 & 4,667 & 4,494 & 4,655 & 186 & 318 \\
\hline 10 & $M T-N D 2$ & 5,244 & 5,244 & + & 5,140 & 5,317 & 5,154 & 5,302 & 178 & 310 \\
\hline 11 & МT-АТР6 & 9,101 & 9,101 & - & 9,026 & 9,223 & 9,041 & 9,208 & 198 & 330 \\
\hline 12 & МТ-СOЗ & 9,804 & 9,804 & - & 9,639 & 9,839 & 9,653 & 9,824 & 201 & 333 \\
\hline 13 & $M T-N D 3$ & 10,237 & 10,237 & - & 10,161 & 10,331 & 10,178 & 10,310 & 171 & 303 \\
\hline 14 & $M T-N D 4 L$ & 10,663 & 10,680 & - & 10,541 & 10,710 & 10,560 & 10,692 & 170 & 302 \\
\hline 15 & $M T-N D 4$ & 11,253 & 11,253 & + & 11,226 & 11,404 & 11,239 & 11,386 & 179 & 311 \\
\hline 16 & $M T-N D 4$ & 11,696 & 11,778 & + & 11,642 & 11,833 & 11,660 & 11,813 & 192 & 324 \\
\hline 17 & MT-ND5 & 12,338 & 12,338 & - & 12,213 & 12,399 & 12,230 & 12,385 & 187 & 319 \\
\hline 18 & MT-ND5 & 12,811 & 12,848 & + & 12,764 & 12,941 & 12,776 & 12,924 & 178 & 310 \\
\hline 19 & $M T-N D 5$ & 13,051 & 13,051 & - & 12,967 & 13,146 & 12,984 & 13,128 & 180 & 312 \\
\hline 20 & $M T-N D 5$ & 13,528 & 13,730 & + & 13,488 & 13,682 & 13,503 & 13,665 & 195 & 327 \\
\hline 21 & $M T-N D 5$ & 13,528 & 13,730 & + & 13,577 & 13,774 & 13,590 & 13,760 & 198 & 330 \\
\hline 22 & $M T-N D 6$ & 14,279 & 14,325 & - & 14,251 & 14,421 & 14,267 & 14,408 & 171 & 303 \\
\hline 23 & $\begin{array}{l}M T-T E \\
M T-N D 6 \\
M T-C Y B\end{array}$ & 14,482 & 14,831 & + & 14,444 & 14,645 & 14,460 & 14,628 & 202 & 334 \\
\hline 24 & $\begin{array}{l}M T-T E \\
M T-N D 6 \\
M T-C Y B\end{array}$ & 14,482 & 14,831 & - & 14,587 & 14,762 & 14,610 & 14,748 & 176 & 308 \\
\hline 25 & $\begin{array}{l}M T-T E \\
M T-N D 6 \\
M T-C Y B\end{array}$ & 14,482 & 14,831 & + & 14,699 & 14,866 & 14,720 & 14,857 & 168 & 300 \\
\hline 26 & $\begin{array}{l}M T-C Y B ; \\
M T-T T\end{array}$ & 15,812 & 15,951 & + & 15,780 & 15,966 & 15,801 & 15,945 & 187 & 319 \\
\hline 27 & $\begin{array}{l}M T-C Y B \\
M T-T T\end{array}$ & 15,812 & 15,951 & - & 15,792 & 15,989 & 15,809 & 15,974 & 198 & 330 \\
\hline
\end{tabular}

PCR, polymerase chain reaction; Tgt, target; prb, probe; var, variation; +, forward primer; -, antisense primer.

previously (16). Notably, three mutations, m.3733G $>$ A, m.4025C $>\mathrm{T}$ and $\mathrm{m} .11253 \mathrm{~T}>\mathrm{C}$, were observed in one LHON case each, but absent in the control cohort. Whereas, $\mathrm{m} .4025 \mathrm{C}>\mathrm{T}$ and $\mathrm{m} .11253 \mathrm{~T}>\mathrm{C}$ were observed in the control population in our recent studies $(8,9)$.

Thirteen secondary mutations were identified in $30.55 \%$ patients. The incidence of these known secondary mutations, m.12811T $>$ C, m.11696G $>$ A, m.3316G $>$ A, m.3394T $>$ C, m.14502T $>$ C, m.3497C $>$ T, m.3571C $>\mathrm{T}, \mathrm{m} .12338 \mathrm{~T}>\mathrm{C}$, m.14693A $>$ G, m.4216T $>$ C, m.15951A $>$ G, m.14831G $>A$ and
m.9804G $>$ A were 5.09, 4.36, 4.00, 4.00, 4.00, 2.55, 1.82, $1.82,1.45,1.09,1.09,0.36$ and $0.36 \%$, respectively. A total of 88 variations from these 13 mutations were observed in patients. Among these, 67 variations were concurrent with either m.11778G $>$ A (59 variations, except 1 from the $\mathrm{m} .3866 \mathrm{~T}>\mathrm{C}$ mutation) or $\mathrm{m} .14484 \mathrm{~T}>\mathrm{C}$ ( 8 variations $)$. Besides the hotspots of $M T-N D 1, M T-N D 4$ and $M T-N D 6$, the $M T-N D 5$ gene was frequently accumulated in the distribution of secondary mutations with an incidence of $6.91 \%$ in the patients. In addition, the incidence of $M T-N D 1, M T-N D 4$ and 
Table III. Summary of sequencing data in the panel for 556 samples.

\begin{tabular}{lr}
\hline Variable & \multicolumn{1}{c}{ Outcome } \\
\hline Total no. of reads & $118,156,518$ \\
Reads mapped to the amplicons & $110,440,487$ \\
(forward primer) & $108,812,285$ \\
Reads mapped to the amplicons & \\
(reverse primer) & $105,107,193$ \\
Reads mapped to the amplicon targets & $3,892,859$ \\
Reads mapped to each amplicon (average) & $7,001.5$ \\
Reads mapped to each sample & 98 \\
per amplicon (mean) & 363 \\
Reads enrichment to the targets, $\%$ (average) & \\
Uniformity of coverage, $\%$ (20\% mean) & \\
Total no. of variants among 46 point mutations & \\
\hline
\end{tabular}

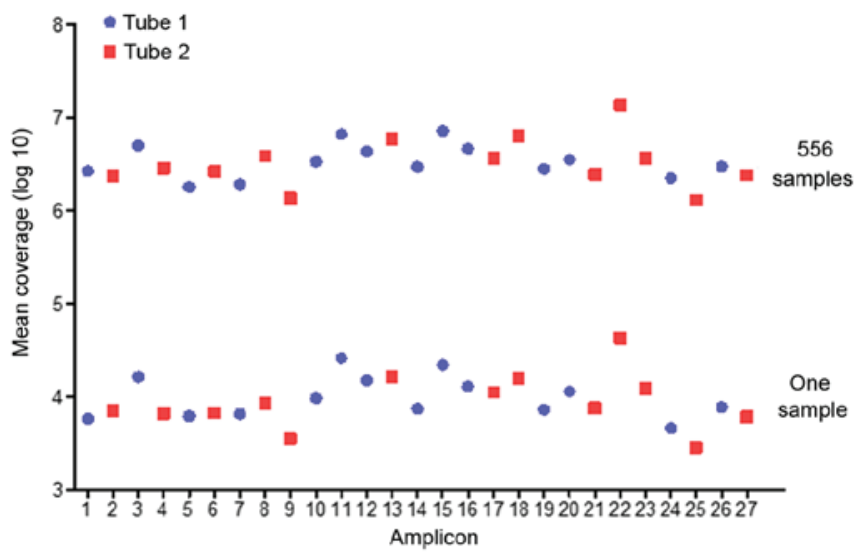

Figure 1. Mean coverage of 27 amplicons. Upper: Average read coverages ( $\log 10)$ for each amplicon (556 samples). Lower: Read coverages $(\log 10)$ for each amplicon from one sample.

MT-ND6 for secondary mutations, were $13.45,4.36$ and $4 \%$, respectively. The secondary mutations were predominantly present in the patient and control populations. Of those, mutations $\mathrm{m} .12338 \mathrm{~T}>\mathrm{C} \mathrm{m} .4216 \mathrm{~T}>\mathrm{C}, \mathrm{m} .3571 \mathrm{C}>\mathrm{T}$ and $\mathrm{m} .14831$ $\mathrm{G}>\mathrm{A}$ had higher incidences in the control cohort than in the patients. Two LHON-associated mutations (m.14325T $>\mathrm{C}$ and $\mathrm{m} .15812 \mathrm{G}>\mathrm{A}$ ) only arose in the control population in the present study.

\section{Discussion}

The present study evaluated the distribution of mitochondrial genes and mutations among 275 Chinese LHON patients, in parallel with a control cohort of 281 subjects, using a multi-gene panel. Mutations of the multi-gene panel were designed from the Mitomap database, previous reports and our previous study in a Chinese Han population (8-10). Twenty-seven amplicons, the specific primers for the point mutations, covered those of 46 mutations, as well as other substitutions in the amplicons, such as pathogenic mutations,
m.3697G $>$ A, m.10197G $>A$ and m.14459G $>$ A in the fragments of amplicon 4, 13 and 23, respectively. None of these three rare causative mutations were recorded among subjects in the test. Of the 46 mutations, the m.14727T $>C$ variant in the $M T-T E$ gene reported in encephalomyopathy patients (17), was set as a negative control variant in the panel and was absent in all of the subjects. The panel with high-throughput sequencing makes it possible to screen multi-genes or multi-single nucleotide polymorphisms (SNPs) for subjects in a run, and provide more information than traditional Sanger sequencing. Certainly, sequencing the whole mtDNA genome is an optional selection using next generation sequencing. The information from the primary and secondary mutations may be indicative regarding the incomplete penetrance and other clinical symptoms.

It is generally accepted that LHON-associated mutations and their incidence are varied in populations with different ethnic backgrounds (18). Consistent results were confirmed in our multi-gene panel screening. Twenty-three mutations in the panels were absent in the patients and control cohort in the current study. Those mutations reported as rare causative mutations in a European LHON population, m.3376G $>$ A, $\mathrm{m} .3700 \mathrm{G}>\mathrm{A}$ and $\mathrm{m} .4171 \mathrm{C}>\mathrm{A}$ in the $M T-N D 1$ gene (19-21), $\mathrm{m} .10663 \mathrm{~T}>\mathrm{C}$ in the $M T-N D 4 L(20), \mathrm{m} .13051 \mathrm{G}>\mathrm{A}$ in the $M T-N D 5$ gene (22), m.14482C $>$ G/A, m.14495A $>\mathrm{G}$ and m.14568C $>\mathrm{T}$ in the $M T$-ND6 gene $(8,20,23)$, were undetected in the present study. However, 6 causative mutations, $\mathrm{m} .11778 \mathrm{G}>\mathrm{A}, \mathrm{m} .14484 \mathrm{~T}>\mathrm{C}, \mathrm{m} .3460 \mathrm{G}>\mathrm{A}, \mathrm{m} .3635 \mathrm{G}>\mathrm{A}$, $\mathrm{m} .3866 \mathrm{~T}>\mathrm{C}$ and $\mathrm{m} .3733 \mathrm{G}>\mathrm{A}$ were observed in $194 \mathrm{LHON}$ cases with their contribution of 83.51, 12.89, 1.04, 0.52, 2.06 and 0.52 . Of these, the incidence of $\mathrm{m} .3460 \mathrm{G}>\mathrm{A}$ was markedly lower in this cohort than that in a Caucasian population reported by Mackey et al (24). Additionally, the spectrum of secondary mutations associated with LHON was also dependent on their ethnic background, and were distinct between the Chinese and Caucasian cohorts. This panel screening demonstrated that the secondary mutations, m.12811T $>C$, m.11696G $>$ A, m.3394T $>C, m .3316 \mathrm{G}>\mathrm{A}, \mathrm{m} .14502 \mathrm{~T}>\mathrm{C}$ and $\mathrm{m} .12338 \mathrm{~T}>\mathrm{C}$ had higher frequencies in the patient cohort, as these mutations were assigned to Asian mtDNA lineage, including the macro-haplo group of $\mathrm{M}$ and $\mathrm{N}$. Certainly, m.12811T $>\mathrm{C}$ is considered to be a polymorphic variant in sub-haplo groups of M7. While, mutations, m.3394T $>$ C and m.11696G $>$ A are categorized as haplo group-specific variants of M9a and D4j, respectively $(25,26)$. Congruent results were obtained in our previous reports (27).

Usually, secondary mutations, proposed to increase the penetrance of LHON (25-27), are observed in LHON cases associated with $\mathrm{m} .11778 \mathrm{G}>\mathrm{A}$ or $\mathrm{m} .14484 \mathrm{~T}>\mathrm{C}$ mutations. In the present study, $77.27 \%$ of variations of secondary mutations were coexistent with one of the primary mutations, m.11778G $>$ A and m.14484T $>$ C. Their detailed distribution was illustrated in Table V. Secondary mutations m.12811T $>C$, $\mathrm{m} .11696 \mathrm{G}>\mathrm{A}, \mathrm{m} .14502 \mathrm{~T}>\mathrm{C}, \mathrm{m} .3394 \mathrm{~T}>\mathrm{C}$ and $\mathrm{m} .3316 \mathrm{G}>\mathrm{A}$ exhibited the most co-occurrence with $\mathrm{m} .11778 \mathrm{G}>\mathrm{A}$. Meanwhile, three LHON cases carried m.14484T $>C$ and m.14502T $>C$ together. Notably, the m.14502T $>C$ mutation was evidenced as a modifier in the phenotypic manifestation of LHON (28), although it was reported as a causative mutation elsewhere (https://www.mitomap.org/foswiki). 
Table IV. Summary information of 46-point mutations in the cohort.

\begin{tabular}{|c|c|c|c|c|c|c|c|c|c|c|}
\hline \multirow[b]{2}{*}{ Index $^{a}$} & \multirow[b]{2}{*}{ Gene } & \multirow[b]{2}{*}{ SNP } & \multirow{2}{*}{$\begin{array}{c}\text { Total } \\
\text { variants }\end{array}$} & \multirow{2}{*}{$\begin{array}{l}\text { Patients } \\
(\mathrm{n}=275)\end{array}$} & \multicolumn{3}{|c|}{ Primer mutations } & \multirow{2}{*}{$\begin{array}{l}\text { Controls } \\
(\mathrm{n}=281)\end{array}$} & \multicolumn{2}{|c|}{ Incidence (\%) } \\
\hline & & & & & 11778 & 14484 & 3460 & & Patients & Controls \\
\hline 1 & $M T-N D 1$ & $3316 \mathrm{G}>\mathrm{A}$ & 15 & 11 & 7 & 1 & 0 & 4 & 4.00 & 1.42 \\
\hline 2 & & $3376 \mathrm{G}>\mathrm{A}$ & 0 & 0 & 0 & 0 & 0 & 0 & 0.00 & 0.00 \\
\hline 3 & & $3394 \mathrm{~T}>\mathrm{C}$ & 19 & 11 & 7 & 0 & 0 & 8 & 4.00 & 2.85 \\
\hline 4 & & $3460 G>A$ & 2 & 2 & 0 & 0 & 2 & 0 & 0.73 & 0.00 \\
\hline 5 & & $3497 \mathrm{C}>\mathrm{T}$ & 14 & 7 & 4 & 0 & 0 & 7 & 2.55 & 2.50 \\
\hline 6 & & $3571 \mathrm{C}>\mathrm{T}$ & 11 & 5 & 3 & 0 & 0 & 6 & 1.82 & 2.14 \\
\hline 7 & & $3635 \mathrm{G}>\mathrm{A}$ & 1 & 1 & 0 & 0 & 0 & 0 & 0.36 & 0.00 \\
\hline 8 & & $3700 \mathrm{G}>\mathrm{A}$ & 0 & 0 & 0 & 0 & 0 & 0 & 0.00 & 0.00 \\
\hline 9 & & $3733 \mathrm{G}>\mathrm{A}$ & 1 & 1 & 0 & 0 & 0 & 0 & 0.36 & 0.00 \\
\hline 10 & & $3866 \mathrm{~T}>\mathrm{C}$ & 4 & 4 & 1 & 0 & 0 & 0 & 1.45 & 0.00 \\
\hline 11 & & $4025 \mathrm{C}>\mathrm{T}$ & 1 & 1 & 0 & 0 & 0 & 0 & 0.36 & 0.00 \\
\hline 12 & & $4171 \mathrm{C}>\mathrm{A}$ & 0 & 0 & 0 & 0 & 0 & 0 & 0.00 & 0.00 \\
\hline 13 & & $4216 \mathrm{~T}>\mathrm{C}$ & 11 & 3 & 0 & 0 & 0 & 8 & 1.09 & 2.85 \\
\hline 14 & $M T-N D 2$ & $4640 \mathrm{C}>\mathrm{A}$ & 0 & 0 & 0 & 0 & 0 & 0 & 0.00 & 0.00 \\
\hline 15 & & $5244 \mathrm{G}>\mathrm{A}$ & 0 & 0 & 0 & 0 & 0 & 0 & 0.00 & 0.00 \\
\hline 16 & MT-АTP 6 & $9101 \mathrm{~T}>\mathrm{C}$ & 0 & 0 & 0 & 0 & 0 & 0 & 0.00 & 0.00 \\
\hline 17 & MT-CO3 & $9804 \mathrm{G}>\mathrm{A}$ & 2 & 1 & 1 & 0 & 0 & 1 & 0.36 & 0.36 \\
\hline 18 & $M T-N D 3$ & $10237 \mathrm{~T}>\mathrm{C}$ & 0 & 0 & 0 & 0 & 0 & 0 & 0.00 & 0.00 \\
\hline 19 & $M T-N D 4 L$ & $10663 \mathrm{~T}>\mathrm{C}$ & 0 & 0 & 0 & 0 & 0 & 0 & 0.00 & 0.00 \\
\hline 20 & & $10680 \mathrm{G}>\mathrm{A}$ & 0 & 0 & 0 & 0 & 0 & 0 & 0.00 & 0.00 \\
\hline 21 & $M T-N D 4$ & $11253 \mathrm{~T}>\mathrm{C}$ & 1 & 1 & 1 & 0 & 0 & 0 & 0.36 & 0.00 \\
\hline 22 & & $11696 \mathrm{G}>\mathrm{A}$ & 18 & 12 & 10 & 1 & 0 & 6 & 4.36 & 2.14 \\
\hline 23 & & $11778 G>A$ & 162 & 162 & 162 & 0 & 0 & 0 & 58.90 & 0.00 \\
\hline 24 & $M T-N D 5$ & $12338 \mathrm{~T}>\mathrm{C}$ & 19 & 5 & 2 & 0 & 0 & 14 & 1.82 & 4.98 \\
\hline 25 & & $12811 \mathrm{~T}>\mathrm{C}$ & 21 & 14 & 12 & 0 & 0 & 7 & 5.09 & 2.49 \\
\hline 26 & & $12848 \mathrm{C}>\mathrm{T}$ & 0 & 0 & 0 & 0 & 0 & 0 & 0.00 & 0.00 \\
\hline 27 & & $13051 \mathrm{G}>\mathrm{A}$ & 0 & 0 & 0 & 0 & 0 & 0 & 0.00 & 0.00 \\
\hline 28 & & $13528 A>G$ & 0 & 0 & 0 & 0 & 0 & 0 & 0.00 & 0.00 \\
\hline 29 & & $13637 \mathrm{~A}>\mathrm{G}$ & 0 & 0 & 0 & 0 & 0 & 0 & 0.00 & 0.00 \\
\hline 30 & & $13730 \mathrm{G}>\mathrm{A}$ & 0 & 0 & 0 & 0 & 0 & 0 & 0.00 & 0.00 \\
\hline 31 & MT-ND6 & $14279 \mathrm{G}>\mathrm{A}$ & 0 & 0 & 0 & 0 & 0 & 0 & 0.00 & 0.00 \\
\hline 32 & & $14325 \mathrm{~T}>\mathrm{C}$ & 2 & 0 & 0 & 0 & 0 & 2 & 0.00 & 0.71 \\
\hline 33 & & $14482 C>A$ & 0 & 0 & 0 & 0 & 0 & 0 & 0.00 & 0.00 \\
\hline 34 & & $14482 C>G$ & 0 & 0 & 0 & 0 & 0 & 0 & 0.00 & 0.00 \\
\hline 35 & & $14484 T>C$ & 25 & 25 & 0 & 25 & 0 & 0 & 9.10 & 0.00 \\
\hline 36 & & $14495 A>G$ & 0 & 0 & 0 & 0 & 0 & 0 & 0.00 & 0.00 \\
\hline 37 & & $14498 \mathrm{~T}>\mathrm{C}$ & 0 & 0 & 0 & 0 & 0 & 0 & 0.00 & 0.00 \\
\hline 38 & & $14502 \mathrm{~T}>\mathrm{C}$ & 18 & 11 & 8 & 3 & 0 & 7 & 4.00 & 2.49 \\
\hline 39 & & $14568 \mathrm{C}>\mathrm{T}$ & 0 & 0 & 0 & 0 & 0 & 0 & 0.00 & 0.00 \\
\hline 40 & & $14596 \mathrm{~A}>\mathrm{T}$ & 0 & 0 & 0 & 0 & 0 & 0 & 0.00 & 0.00 \\
\hline 41 & $M T-C Y B$ & $14831 \mathrm{G}>\mathrm{A}$ & 5 & 1 & 0 & 0 & 0 & 4 & 0.36 & 1.42 \\
\hline 42 & & $15812 \mathrm{G}>\mathrm{A}$ & 1 & 0 & 0 & 0 & 0 & 1 & 0.00 & 0.36 \\
\hline 43 & $M T-T M$ & $4435 \mathrm{~A}>\mathrm{G}$ & 0 & 0 & 0 & 0 & 0 & 0 & 0.00 & 0.00 \\
\hline 44 & $M T-T T$ & $15951 A>G$ & 5 & 3 & 1 & 2 & 0 & 2 & 1.09 & 0.71 \\
\hline 45 & $M T-T E$ & $14693 \mathrm{~A}>\mathrm{G}$ & 5 & 4 & 3 & 1 & 0 & 1 & 1.45 & 0.36 \\
\hline \multirow[t]{2}{*}{46} & & $14727 \mathrm{~T}>\mathrm{C}$ & 0 & 0 & 0 & 0 & 0 & 0 & 0.00 & 0.00 \\
\hline & & $\begin{array}{c}\text { Total } \\
\text { variants }\end{array}$ & 363 & 285 & $\begin{array}{l}162^{\mathrm{b}} \\
(60)\end{array}$ & $\begin{array}{l}25^{c} \\
(8)\end{array}$ & 2 & 78 & 103.64 & 27.76 \\
\hline
\end{tabular}

${ }^{a}$ The index number is according to Table I; ${ }^{b} 162$ subjects carrying the m.11778G $>$ A mutation, of which 60 subjects were carrying the $\mathrm{m} .11778 \mathrm{G}>\mathrm{A}$ and one of the secondary variants; ${ }^{2} 25$ subjects carrying the m.14484T $>\mathrm{C}$ mutation, of which 8 subjects were carrying the m.14484T $>$ C and a secondary variant. The three common mutations for LHON are emboldened. SNP, single nucleotide polymorphism. 
Table V. Distribution of secondary mutations with m.11778 G>A and m.14484 T>C.

Secondary mutation (cases harboring successive secondary mutations, $\mathrm{n}$ )

\begin{tabular}{|c|c|c|c|c|}
\hline \multirow{2}{*}{$\begin{array}{l}\text { Primary } \\
\text { mutation }\end{array}$} & & \multirow[b]{2}{*}{ Samples, $\mathrm{n}$} \\
\hline & 1 & 2 & 3 & \\
\hline & $12811 \mathrm{~T}>\mathrm{C}$ & - & - & 12 \\
\hline & $11696 \mathrm{G}>\mathrm{A}$ & $3394 \mathrm{~T}>\mathrm{C}$ (1) & - & 10 \\
\hline & $14502 \mathrm{~T}>\mathrm{C}$ & $14693 \mathrm{~A}>\mathrm{G}$ & $9804 \mathrm{G}>\mathrm{A}(1)$ & 8 \\
\hline & & $3866 \mathrm{~T}>\mathrm{C}(1)$ & - & \\
\hline & $3316 \mathrm{G}>\mathrm{A}$ & - & - & 7 \\
\hline \multirow[t]{8}{*}{$11778 \mathrm{G}>\mathrm{A}$} & $3394 \mathrm{~T}>\mathrm{C}$ & 11696 G>A (1) & - & 7 \\
\hline & $3497 \mathrm{C}>\mathrm{T}$ & 3571 C>T (3) & - & 4 \\
\hline & $14693 \mathrm{~A}>\mathrm{G}$ & $14502 \mathrm{~T}>\mathrm{C}(1)$ & - & 3 \\
\hline & $3571 \mathrm{C}>\mathrm{T}$ & 3497 C >T (3) & - & 3 \\
\hline & $12338 \mathrm{~T}>\mathrm{C}$ & - & - & 2 \\
\hline & $9804 \mathrm{G}>\mathrm{A}$ & $14502 \mathrm{~T}>\mathrm{C}(1)$ & $14693 \mathrm{~A}>\mathrm{G}$ & 1 \\
\hline & $11253 \mathrm{~T}>\mathrm{C}$ & - & - & 1 \\
\hline & $15951 \mathrm{~A}>\mathrm{G}$ & - & - & 1 \\
\hline \multirow[t]{5}{*}{$14484 \mathrm{~T}>\mathrm{C}$} & $14502 \mathrm{~T}>\mathrm{C}$ & - & - & 3 \\
\hline & $15951 \mathrm{~A}>\mathrm{G}$ & - & - & 2 \\
\hline & $11696 \mathrm{G}>\mathrm{A}$ & - & - & 1 \\
\hline & $3316 \mathrm{G}>\mathrm{A}$ & - & - & 1 \\
\hline & $14693 \mathrm{~A}>\mathrm{G}$ & - & - & 1 \\
\hline
\end{tabular}

Furthermore, more than one secondary mutation co-occurred with $\mathrm{m} .11778 \mathrm{G}>\mathrm{A}$, but not with $\mathrm{m} .14484 \mathrm{~T}>\mathrm{C}$ in this panel. $\mathrm{m} .3497 \mathrm{C}>\mathrm{T}$ and $\mathrm{m} .3571 \mathrm{C}>\mathrm{T}$, which belong to the haplo group variants of $\mathrm{B} 4 \mathrm{c} 1$, arose in three cases associated with m.11778G $>$ A . In addition, m.9804G $>A$ and $\mathrm{m} .14831 \mathrm{G}>\mathrm{A}$, reported as LHON-associated mutations in Caucasian cases, were common in the present control cohort according to the panel analysis. It was confirmed that the spectrum of mutations varied between ethnic backgrounds and indicated that the selected SNPs of the panel would be optimized for a Han population in the future.

In conclusion, the current data indicates that the spectrum and incidence of mtDNA mutation-associated LHON cases in the Han population are different to those in a Caucasian population. Here, the causative mutations associated with LHON, m.11778G $>$ A, m.14484T $>$ C, m.3460G $>$ A, $\mathrm{m} .3635 \mathrm{G}>\mathrm{A}, \mathrm{m} .3866 \mathrm{~T}>\mathrm{C}$ and $\mathrm{m} .3733 \mathrm{G}>\mathrm{A}$, were observed in $70.55 \%$ of the patient cohort. The common secondary mutations in the Chinese LHON population were m.12811T $>\mathrm{C}$, m.11696G $>$ A, m.3394T $>C, m .3316 G>A, m .14502 T>C$ and m.12338T $>C$. Furthermore, besides the three hotspots genes $M T-N D 1, M T-N D 4$ and MT-ND6, MT-ND5 also had a high incidence of secondary mutations including m.12811T $>\mathrm{C}$ and $\mathrm{m} .12338 \mathrm{~T}>\mathrm{C}$; this finding was comparable with a previous study (29). The primary and secondary mutation-associated LHON cases in the present multi-gene panel will advance current understanding of the clinical phenotype of LHON, and offer valuable information for the early diagnosis and subsequent options of intervention for mitigating risk of additional vision loss in LHON patients.

\section{Acknowledgements}

The present study was supported by the National Technologies R\&D Program (grant no. 2012BAI09B03) and a grant from the National Natural Science Foundation of China (grant no. 31671303$)$.

\section{References}

1. Y-W-Man P, Griffiths PG, Brown DT, Howell N, Turnbull DM and Chinnery PF: The epidemiology of Leber hereditary optic neuropathy in the North East of England. Am J Hum Genet 72: 333-339, 2003.

2. Saracchi E, Difrancesco JC, Brighina L, Marzorati L, Curtò NA, Lamperti C, Carrara F, Zeviani M and Ferrarese C: A case of Leber hereditary optic neuropathy plus dystonia caused by G14459A mitochondrial mutation. Neurol Sci 34: 407-408, 2013.

3. Howell $\mathrm{N}$ and Mackey DA: Low-penetrance branches in matrilineal pedigrees with Leber hereditary optic neuropathy. Am J Hum Genet 63: 1220-1224, 1998.

4. Fraser JA, Biousse V and Newman NJ: The neuro-ophthalmology of mitochondrial disease. Surv Ophthalmol 55: 299-334, 2010.

5. Yu-Wai-Man P, Griffiths PG and Chinnery PF: Mitochondrial optic neuropathies - disease mechanisms and therapeutic strategies. Prog Retin Eye Res 30: 81-114, 2011.

6. Kim SH and Kim JS: Leber's 'Plus' in a Korean patient with 14484/ND6 mutation. J Clin Neurol 12: 512-514, 2016.

7. Jia X, Li S, Xiao X, Guo X and Zhang Q: Molecular epidemiology of mtDNA mutations in 903 Chinese families suspected with Leber hereditary optic neuropathy. J Hum Genet 51: 851-856, 2006.

8. Ji Y, Liang M, Zhang J, Zhu L, Zhang Z, Fu R, Liu X, Zhang M, Fu Q, Zhao F, et al: Mitochondrial ND1 variants in 1281 Chinese subjects with Leber's hereditary optic neuropathy. Invest Ophthalmol Vis Sci 57: 2377-2389, 2016.

9. Jiang P, Liang M, Zhang J, Gao Y, He Z, Yu H, Zhao F, Ji Y, Liu X, Zhang M, et al: Prevalence of mitochondrial ND4 mutations in 1281 Han Chinese subjects with Leber's hereditary optic neuropathy. Invest Ophthalmol Vis Sci 56: 4778-4788, 2015. 
10. Liang M, Jiang P, Li F, Zhang J, Ji Y,He Y, Xu M, Zhu J, Meng X, Zhao F, et al: Frequency and spectrum of mitochondrial ND6 mutations in 1218 Han Chinese subjects with Leber's hereditary optic neuropathy. Invest Ophthalmol Vis Sci 55: 1321-1331, 2014.

11. Yu-Wai-Man P and Chinnery PF: Leber hereditary optic neuropathy. In: GeneReviews ${ }^{\circledR}$ [Internet]. Pagon RA, Adam MP, Ardinger HH, Wallace SE, Amemiya A, Bean LJH, Bird TD, Fong CT, Mefford HC and Smith RJH (eds). University of Washington, Seattle, WA, 1993-2016.

12. Qu J, Li R, Zhou X, Tong Y, Lu F, Qian Y, Hu Y, Mo JQ, West CE and Guan MX: The novel A4435G mutation in the mitochondrial tRNAMet may modulate the phenotypic expression of the LHON-associated ND4 G11778A mutation. Invest Ophthalmo Vis Sci 47: 475-483, 2006.

13. Li X, Liu L, Xi Q, Zhao X, Fang M, Ma J, Zhu Z, Wang X, Shi C, Wang J, et al: Short-term serum deprivation causes no significant mitochondrial DNA mutation in vascular smooth muscle cells revealed by a new next generation sequencing technology. Acta Biochim Biophys Sin (Shanghai) 48: 862-864, 2016.

14. Li H and Durbin R: Fast and accurate short read alignment with Burrows-Wheeler transform. Bioinformatics 25: 1754-1760, 2009.

15. Andrews RM, Kubacka I, Chinnery PF, Lightowlers RN, Turnbull DM and Howell N: Reanalysis and revision of the Cambridge reference sequence for human mitochondrial DNA. Nat Genet 23: 147, 1999.

16. Zhou X, Qian Y, Zhang J, Tong Y, Jiang P, Liang M, Dai X, Zhou H, Zhao F, Ji Y, et al: Leber's hereditary optic neuropathy is associated with the T3866C mutation in mitochondrial ND1 gene in three Han Chinese families. Invest Ophthalmol Vis Sci 53: 4586-4594, 2012.

17. Truong HT, Nguyen VA, Nguyen LV, Pham VA and Phan TN: Screening of common point-mutations and discovery of new T14727C change in mitochondrial genome of Vietnamese encephalomyopathy patients. Mitochondrial DNA A DNA Mapp Seq Anal 27: 441-448, 2016.

18. Wallace DC and Lott MT: Leber hereditary optic neuropathy: Exemplar of an mtDNA disease. Handb Exp Pharmacol 240: 339-376, 2017

19. Blakely EL, de Silva R, King A, Schwarzer V, Harrower T, Dawidek G, Turnbull DM and Taylor RW: LHON/MELAS overlap syndrome associated with a mitochondrial MTND1 gene mutation. Eur J Hum Genet 13: 623-627, 2005.
20. Achilli A, Iommarini L, Olivieri A, Pala M, Hooshiar Kashani B, Reynier P, La Morgia C, Valentino ML, Liguori R, Pizza F, et al: Rare primary mitochondrial DNA mutations and probable synergistic variants in Leber's hereditary optic neuropathy. PLoS One 7: e42242, 2012.

21. Kim JY,Hwang JM and Park SS: MitochondrialDNA C4171A/ND1 is a novel primary causative mutation of Leber's hereditary optic neuropathy with a good prognosis. Ann Neurol 51: 630-634, 2002.

22. Fauser S, Leo-Kottler B, Besch D and Luberichs J: Confirmation of the 14568 mutation in the mitochondrial ND6 gene as causative in Leber's hereditary optic neuropathy. Ophthalmic Genet 23: 191-197, 2002.

23. Chinnery PF, Brown DT, Andrews RM, Singh-Kler R, RiordanEva P, Lindley J, Applegarth DA, Turnbull DM and Howell N: The mitochondrial ND6 gene is a hot spot for mutations that cause Leber's hereditary optic neuropathy. Brain 124: 209-218, 2001.

24. Mackey DA, Oostra RJ, Rosenberg T, Nikoskelainen E, BronteStewart J, Poulton J, Harding AE, Govan G, Bolhuis PA and Norby S: Primary pathogenic mtDNA mutations in multigeneration pedigrees with Leber hereditary optic neuropathy. Am J Hum Genet 59: 481-485, 1996.

25. Zhang M, Zhou X, Li C, Zhao F, Zhang J, Yuan M, Sun YH, Wang J, Tong Y, Liang M, et al: Mitochondrial haplogroup M9a specific variant ND1 T3394C may have a modifying role in the phenotypic expression of the LHON-associated ND4 G11778A mutation. Mol Genet Metab 101: 192-199, 2010.

26. Qu J, Li R, Zhou X, Tong Y, Yang L, Chen J, Zhao F, Lu C, Qian Y, Lu F and Guan MX: Cosegregation of the ND4 G11696A mutation with the LHON-associated ND4 G11778A mutation in a four generation Chinese family. Mitochondrion 7: 140-146, 2007.

27. Sudoyo H, Suryadi H, Lertrit P, Pramoonjago P, Lyrawati D and Marzuki S: Asian-specific mtDNA backgrounds associated with the primary G11778A mutation of Leber's hereditary optic neuropathy. J Hum Genet 47: 594-604, 2002.

28. Jiang $P$, Liang M, Zhang C, Zhao X, He Q, Cui L, Liu X, Sun YH, $\mathrm{Fu}$ Q, Ji Y, et al: Biochemical evidence for a mitochondrial genetic modifier in the phenotypic manifestation of Leber's hereditary optic neuropathy-associated mitochondrial DNA mutation. Hum Mol Genet 25: 3613-3625, 2016.

29. Seong MW, Choi J, Park SS, Kim JY and Hwang JM: Novel MT-ND5 gene mutation identified in Leber's hereditary optic neuropathy patient using mitochondrial genome sequencing. J Neurol Sci 375: 301-303, 2017. 